\author{
Beata Świątkowska \\ Wojciech Sobala \\ Zuzanna Szubert \\ Urszula Wilczyńska
}

\title{
ASBESTOS RELATED DISEASES AMONG WORKERS OF ASBESTOS PROCESSING PLANTS IN RELATION TO TYPE OF PRODUCTION AND ASBESTOS USE
}

\author{
CHOROBY AZBESTOZALEŻNE WŚRÓD PRACOWNIKÓW ZAKŁADÓW PRZETWÓRSTWA AZBESTU \\ W ZALEŻNOŚCI OD RODZAJU PRODUKCJI I ZUŻYCIA AZBESTU
}

Nofer Institute of Occupational Medicine / Instytut Medycyny Pracy im. prof. J. Nofera, Łódź, Poland

Department of Environmental Epidemiology / Zakład Epidemiologii Środowiskowej

\begin{abstract}
Background: Asbestos dust is one of the most dangerous pneumoconiotic and carcinogenic agents. The aim of this study was to assess the occurrence of asbestosis and pleural mesothelioma, depending on asbestos consumption and the type of manufactured products, among former asbestos workers in Poland. Material and Methods: The study subjects included employees of 18 large state-owned asbestos processing enterprises operating in the Polish market in 1945-1998. The study is based on data obtained from asbestos company records and the Central Register of Occupational Diseases data on the cases of asbestosis and mesothelioma for the period from 1970 till 2012 as well as data from Amiantus Programme. The analysis was performed for 5 sectors comprising plants classified according to the products manufactured and applied production technology. Results: In the study period, 2160 cases of asbestosis and 138 cases of mesothelioma were reported. The plants processed a total of about 2 million tonnes of asbestos, including about $7.5 \%$ of crocidolite. Total asbestos consumption was a strong predictor of the rate of asbestosis incidence $\left(\mathrm{R}^{2}=0.68, \mathrm{p}=0.055\right)$. The highest risk occurrence of asbestosis was observed in the production of textiles and sealing products. Mesothelioma occurred only in plants where crocidolite had been ever processed. Conclusions: Total asbestos consumption was a strong predictor of the rate of asbestosis incidence. The observation confirms the relationship between exposure to crocidolite and the occurrence of mesothelioma, regardless of the manufactured products, and suggests the absence of such a link for the total volume of asbestos consumption. Med Pr 2015;66(1):1-9
\end{abstract}

Key words: asbestosis, mesothelioma, asbestos processing plants, asbestos consumption, chrysotile, crocidolite

\section{STRESZCZENIE}

Wstęp: Azbest jest jednym z najbardziej niebezpiecznych czynników pylico- i rakotwórczych. Celem pracy była ocena występowania azbestozy i międzybłoniaka opłucnej wśród byłych pracowników zakładów przetwórstwa azbestu w Polsce w zależności od zużycia azbestu i typu wytwarzanych produktów. Materiał i metody: Badaniem objęto pracowników 18 dużych państwowych zakładów przetwórstwa azbestu, funkcjonujących w Polsce w latach 1945-1998. Badanie oparto na danych uzyskanych z dokumentacji zakładów i danych Centralnego Rejestru Chorób Zawodowych dotyczących przypadków azbestozy i międzybłoniaka opłucnej, zarejestrowanych w latach 1970-2012, a także danych z programu Amiantus. Analizę przeprowadzono dla 5 branż przemysłu azbestowego, grupując zakłady według typu wyrobów i stosowanej technologii. Wyniki: W okresie objętym badaniem stwierdzono 2160 przypadków azbestozy i 138 międzybłoniaków. W zakładach przetworzono łącznie ok. 2 mln ton azbestu, w tym ok. 7.5\% krokidolitu. Ogólna ilość zużytego w danej branży azbestu okazała się silnym predyktorem zapadalności na azbestozę $\left(\mathrm{R}^{2}=0,68\right.$, $\mathrm{p}=0,055$ ). Najwyższe ryzyko wystąpienia azbestozy zaobserwowano przy produkcji wyrobów włókienniczych i uszczelniających. Międzybłoniak wystąpił tylko u pracowników zakładów, w których kiedykolwiek stosowano krokidolit. Wnioski: Stwierdzono znaczne zróżnicowanie ryzyka występowania azbestozy w zależności od ilości zużytego azbestu. Analiza potwierdziła zależność między narażeniem na azbest krokidolitowy a pojawianiem się międzybłoniaków, niezależnie od produkowanych wyrobów, oraz sugeruje brak tego typu powiązań między ogólną ilością zużytego azbestu. Med. Pr. 2015;66(1):1-9

Słowa kluczowe: azbestoza, międzybłoniak, zakłady przetwórstwa azbestu, zużycie azbestu, chryzotyl, krokidolit

Corresponding author / Autorka do korespondencji: Neonila Szeszenia-Dąbrowska, Nofer Institute of Occupational Medicine, Department of Occupational and Environmental Epidemiology, św. Teresy 8, 91-348 Łódź, Poland, e-mail: wies@imp.lodz.pl Received: 2014, May 28, accepted: 2014, October 29

Funding / Finansowanie: this work was performed under the project: "Risk assessment of the incidence and mortality due to asbestos-related diseases among workers occupationally exposed to asbestos on the basis of the long-term epidemiological observation”, IMP 10.14. Manager of the project: Neonila Szeszenia-Dąbrowska, Prof. 


\section{INTRODUCTION}

Asbestos dust is one of the most dangerous pneumoconiotic and carcinogenic agents. Occupational exposure to asbestos is a cause factor for asbestosis and increases the risk for mesothelioma and lung cancer. In Poland, as in many other countries, asbestos is classified as a carcinogenic agent to humans. The consequence of this is the law introduced in 1997 which bans the import, manufacturing and sale of asbestos and asbestos-containing materials. In spite of the fact that asbestos plants have been closed, the use of asbestos has been banned for 16 years, and that crocidolite asbestos has been banned since the mid-80s of the last century, cases of the diseases induced by this carcinogen continue to be recorded among the former workers of asbestos-processing plants. Asbestos-induced damage is generally permanent and irreversible and it causes a life-altering disability. Asbestos-related diseases often develop after exposure termination, and the symptoms frequently appear after a long time from the 1st contact with asbestos; for asbestosis, that period amounts to 10-20 years, while for pleural mesothelioma, the minimum length of that period is 10 years, but usually it ranges from 20 to 40 years [1].

Practical indestructibility of asbestos fibres, large quantities of asbestos-containing products introduced into the environment combined with continuing reports about new asbestos-related tumour cases cause that former, as well as current, occupational and environmental exposure to asbestos still constitutes a considerable public health problem [2-6].

There is evidence from ecological studies that asbestos consumption predicts the incidence of mesothelioma in general population but the amount and type of processed asbestos was not taken into account as a risk predictor of asbestos-related diseases for the working population.

The aim of this work was to assess the frequency of asbestosis and pleural mesothelioma among workers of asbestos processing plants in Poland, classified according to the products manufactured and related technology, and according to the amount and type of asbestos processed.

\section{MATERIAL AND METHODS}

The analysis is based on data obtained from former asbestos company records and the Central Register of Occupational Diseases in Poland. The study included 18 large state-owned asbestos processing enterpri- ses operating in Poland since 1945. For each plant, historical data on the life cycle, product range, technology used, the amount and the type of processed asbestos as well as the number of employees was collected. Analyses were performed in 5 groups of plants, classified according to the type of manufactured products and the processing technology used. The following plants, classified according to the type of products, were included in the analysis: asbestos-cement plants (8 factories), textile ( 2 factories), sealing ( 2 factories), friction ( 2 factories) and waterproofing plants (4 factories).

As in ecological research, the quantity of asbestos used for the production of specific products was assumed as an indicator of the potential asbestos risk. We defined the health outcome as the number of cases per 1000 employees, the number of cases per $10000 \mathrm{t}$ of the asbestos processed, and the amount of asbestos consumption (tonnes during 1945-1999) per 1 worker as an exposure indicator.

The asbestos-related diseases included in the study were: asbestosis caused only by asbestos exposure and mesothelioma, for which asbestos is essentially the only known cause. The analysis did not include lung cancer because no data was available on smoking cigarettes by persons employed in various industries, including those with diagnosed occupational disease. It should be noted that in Poland, every case of lung cancer with documented exposure to asbestos is compensated as an occupational disease, no matter whether asbestosis had been diagnosed beforehand, and irrespective of the smoking habit. The incidence data was obtained from the Central Register of Occupational Diseases which keeps the records of all of the reported and certified occupational diseases in Poland. The analysis included all 2160 cases of asbestosis and 138 cases of mesothelioma, starting from the earliest recorded ones, until those detected in 2012.

Relationships between asbestosis and pleural mesothelioma rates and asbestos consumption were analysed using quasi-binomial regression with identity link [7]. We used regression coefficients $\left(B_{1}\right)$ and respective $95 \%$ confidence intervals (CIs) to estimate the associations. The coefficient of determination (adjusted $\mathrm{R}^{2}$ ) was calculated to evaluate regression models. Crocidolite and total asbestos consumption were log-transformed in the models for asbestosis. We presented the slope coefficient as a measure of asbestos use impact (volume per one case). All values of $\mathrm{p}<0.05$ were accepted as statistically significant. Statistical models were equipped with R statistical programme, version 3.0.1. 


\section{RESULTS}

\section{Characteristics of plants}

Plants producing asbestos-containing products are listed in the "Act banning the use of asbestos" which became the basis for the implementation of preventive examinations for former employees of these companies in 2000 (Amiantus Programme). The use of asbestos as raw material in the production served as the inclusion criterion. The list included large state-owned enterprises which employed hundreds of workers, as well as some workshops employing a dozen of people. The workshops were not included in the analysis because data on their activities was not available. This applies mainly to manufacturers of small-sized asbestos-cement and friction products.

The plants included in the survey, since 1945 to 1998 , i.e., till the implementation of the law banning the use of asbestos, processed over 2 million tonnes of asbestos, including ca. 151 thousand tonnes of crocidolite (Table 1). The majority, approximately $92.5 \%$, was chrysotile imported mainly from the former Soviet Union. Given the data obtained from the plants, it is estimated that over 43.6 thousand of individuals were occupationally exposed to asbestos dust.

Asbestos supplied to plants, regardless of the final product, first of all required to be opened, i.e., separated into individual fibres by a method capable of keeping to the minimum losses associated with breaking/ shortening of fibres. Asbestos was opened in grinding mills using dry, semi-dry or wet processes. The process was preceded by ripping the bags and feeding the material into a grinder mill. Until the mid-seventies, these procedures were performed manually in most plants. The highest concentrations of the dust were recorded at the workplaces occupied by feeders, operators of grinder mills, as well as operators of cutting and polishing units. Among the studied sectors, the highest concentrations of asbestos fibres were recorded in the production of yarn, woven fabrics and other insulation materials.

The production of asbestos-cement was the largest asbestos processing sector which, in 8 large stateowned plants, processed about $82 \%$ of the total asbestos imported to Poland. The main material used for the manufacture of asbestos-cement was chrysotile but, since the mid-eighties, considerable quantities of crocidolite and small amounts of amosite were used to produce pressure pipes.

Asbestos-cement corrugated and flat sheets were produced in Poland using almost identical formulations: $88 \%$ to $91 \%$ of cement, and $9 \%$ to $12 \%$ of asbestos in terms of dry weight. Occasionally, chrysotile asbestos was supplemented with $3 \%$ to $5 \%$ of crocidolite. Larger quantities of crocidolite (up to $20 \%$ of asbestos) were used in the production of asbestos-cement pipes, manufactured in only 1 plant. Since the mid-eighties, the use of crocidolite has been banned.

The production of asbestos-cement continued from 1945 to 1998, individual plants were in operation for periods ranging from 14 to 46 years. It is estimated that employment during that period was about 18 thousand of employees.

The textile plants included in the survey produced yarn, rope, non-woven fabric, thermal insulating fabric woven from asbestos yarn, insulation tape used e.g., for the insulation of steam boilers, heat exchangers, piping,

Table 1. Characteristics of asbestos processing plants according to the type of products Tabela 1. Charakterystyka zakładów przetwórstwa azbestu według rodzaju produktów

\begin{tabular}{|c|c|c|c|c|c|c|}
\hline $\begin{array}{l}\text { Type of products } \\
\text { Rodzaj produktów }\end{array}$ & $\begin{array}{l}\text { Period } \\
\text { of plants } \\
\text { operation } \\
\text { Okres } \\
\text { działania } \\
\text { zakładów }\end{array}$ & \multicolumn{2}{|c|}{$\begin{array}{c}\text { Asbestos consumption } \\
\text { Zużycie azbestu }\end{array}$} & $\begin{array}{c}\text { Workers } \\
\text { Pracownicy } \\
\text { [n] }\end{array}$ & $\begin{array}{c}\text { Asbestos } \\
\text { consumption } \\
\text { per } 1 \text { worker } \\
\text { Zużycie azbestu } \\
\text { na } 1 \text { pracownika } \\
\text { [t] }\end{array}$ & $\begin{array}{c}\text { Crocidolite } \\
\text { consumption } \\
\text { per } 1 \text { worker } \\
\text { Zużycie } \\
\text { krokidolitu } \\
\text { na } 1 \text { pracownika } \\
\text { [t] }\end{array}$ \\
\hline Textile / Włókiennicze & $1945-1997$ & 220000 & 1.1 & 9700 & 22.7 & 0.3 \\
\hline Sealants / Uszczelniające & $1945-1999$ & 80000 & 7.5 & 7700 & 10.4 & 0.8 \\
\hline Frictional / Cierne & $1956-1995$ & 40000 & - & 4500 & 8.9 & 0.0 \\
\hline Waterproofing / Hydroizolacyjne & $1953-1992$ & 22000 & 25.0 & 3850 & 5.7 & 1.4 \\
\hline
\end{tabular}


and to manufacture fire-resistant clothes. These products contained from $75 \%$ to $90 \%$ of asbestos. Overall, the textile sector processed about $11 \%$ of the total asbestos imported to Poland, including about $1 \%$ of crocidolite. It is estimated that ca. 9700 employees were exposed to asbestos dust in the asbestos-processing textile factories.

The plants of sealing products manufactured asbestos-rubber board, cardboard, various types of gaskets and braided sealants made from asbestos yarn. The content of asbestos in these products ranged from $40 \%$ to $90 \%$. The plants used chrysotile imported from the former Soviet Union and, until 1984, small amounts of blue asbestos. In total, over 35 years, the plants converted about $4 \%$ of imported asbestos, including about $7.5 \%$ of crocidolite. It is estimated that approximately 7700 employees were exposed to asbestos dust in the plants manufacturing asbestos sealing products.

The plants of friction products manufactured: friction linings and brake band used for clutches and brakes for various types of motor vehicles, cranes, elevators, conveyors and other mobile devices, drum brake and clutch linings, brake pads. The products contained from $27 \%$ to $43 \%$ of chrysotile asbestos. In total, over 39 years, about $2 \%$ of the imported chrysotile was processed. The crocidolite asbestos was not used in the production of these products. It is estimated that the number of employees exposed to asbestos dust in the friction products plants was about 4500 .

The production of a variety of waterproofing items was the smallest sector of the asbestos processing industry. The waterproofing products included filling materials (sealants, primer solutions, glues, asphalt emulsions), lubricants for industrial concrete, dry mortar, products for use in road construction and additives for concrete, asphalt binders, cements, sealants, refined road asphalt, mortar primers, tar roof, floor tile. That sector processed about $1 \%$ of the total imported asbestos, of which up to $25 \%$ was crocidolite. Asbestos content in the waterproofing products ranged from $3 \%$ to $30 \%$, while in the sealants, the average asbestos content was about $40 \%$. A significant part of the work, including handling and feeding loose asbestos stock to the machines, was performed manually. These products were manufactured for 39 years, since 1953 till 1992. It is estimated that over 3800 people were exposed to asbestos dust during that period.

\section{The occurrence of occupational asbestos-related diseases in asbestos processing plants}

\section{Asbestosis}

There were 2160 cases of asbestosis recorded in the period from the 1st case reported in 1970 till 2012 (Table 2). Out of this number, $50.6 \%$ of cases were identified in the period from 2001 to 2012, i.e., during the period covered by the Amiantus Programme. Before the implementation of this project, the average number of cases per year had been 34.4, while for the period over the years 2001-2012, the corresponding number was 91.1. The cases reported in the asbestos processing plants accounted for $73.2 \%$ of the total number of asbestosis observed in Poland during this period, but the highest risk of developing asbestosis

Table 2. Asbestos-related occupational diseases according to branches of asbestos processing plants, 1970-2012 Tabela 2. Azbestozależne choroby zawodowe według branż przetwórstwa azbestu w latach 1970-2012

\begin{tabular}{|c|c|c|c|c|c|c|}
\hline \multirow[b]{2}{*}{$\begin{array}{l}\text { Type of products } \\
\text { Rodzaj produktów }\end{array}$} & \multicolumn{3}{|c|}{$\begin{array}{c}\text { Asbestosis } \\
\text { Azbestoza } \\
{[n]}\end{array}$} & \multicolumn{3}{|c|}{$\begin{array}{l}\text { Mesothelioma } \\
\text { Międzybłoniak } \\
\text { [n] }\end{array}$} \\
\hline & $\begin{array}{l}\text { cases } \\
\text { (total) } \\
\text { przypadki } \\
\text { (ogółem) }\end{array}$ & $\begin{array}{c}\text { cases per } \\
1000 \text { workers } \\
\text { przypadki } \\
\text { na } 1000 \\
\text { pracowników }\end{array}$ & $\begin{array}{c}\text { cases per } 10000 \mathrm{t} \\
\text { of asbestos } \\
\text { przypadki } \\
\text { na } 10000 \mathrm{t} \\
\text { azbestu }\end{array}$ & $\begin{array}{l}\text { cases } \\
\text { (total) } \\
\text { przypadki } \\
\text { (ogółem) }\end{array}$ & $\begin{array}{c}\text { cases per } \\
1000 \text { workers } \\
\text { przypadki } \\
\text { na } 1000 \\
\text { pracowników }\end{array}$ & $\begin{array}{c}\text { cases per } 10000 \mathrm{t} \\
\text { of crocidolite } \\
\text { przypadki } \\
\text { na } 10000 \mathrm{t} \\
\text { krokidolitu }\end{array}$ \\
\hline Asbestos-cement / Azbestowo-cementowe & 1211 & 67.65 & 7.3 & 117 & 6.54 & 8.5 \\
\hline Textile / Włókiennicze & 675 & 69.59 & 39.7 & 2 & 0.21 & 8.3 \\
\hline Sealants / Uszczelniające & 220 & 28.57 & 27.5 & 5 & 0.65 & 8.3 \\
\hline Frictional / Cierne & 25 & 5.56 & 6.2 & 0 & 0.00 & 0.0 \\
\hline Waterproofing / Hydroizolacyjne & 29 & 7.53 & 13.2 & 14 & 3.64 & 25.5 \\
\hline Total / Ogółem & 2160 & 49.48 & 10.7 & 138 & 3.16 & 9.1 \\
\hline
\end{tabular}


was in the textile sector, while the lowest in the sector of frictional materials.

The relationship between the asbestosis incidence rate per 1000 workers and the total asbestos consumption per capita is presented in Figure 1. The range of asbestos use from 5 to $90 \mathrm{t}$ corresponds to the incidence rate of asbestosis, which is between 5 and 67. After excluding asbestos-cement factories, the approximate linear relation between asbestosis rate and the total asbestos use can be clearly observed. The association between asbestos-related diseases and the type of processed asbestos is expressed in Table 3, with the parameters: intercept $\mathrm{B}_{0}$, slope $B_{1}$ and adjusted $R^{2}$ values. The total asbestos consumption was a positive predictor of asbestosis incidence rate, with an adjusted $\mathrm{R}^{2}$ value of $0.68(\mathrm{p}=0.055)$. However, no significant association was found between the crocidolite consumption per capita and the asbestosis incidence rate per 1000 workers $(p=0.483)$.

The asbestosis rate was about 49 per 1000 employed workers and approximately 11 cases of asbestosis were associated with every $10000 \mathrm{t}$ of the asbestos processed. Both of these measures showed differences depending on the product range manufactured in the plants (Table 2).

Chest radiography and detection of the changes in the X-ray chest image are crucial in diagnosing asbestosis. The diagnosis of asbestosis relies on detecting the presence of X-ray changes as small irregular s-, t-, u-type opacities with density starting from $1 / 0$. It is in accordance with the radiological classification of pneumoconiosis developed by the International Labour Office (ILO) [8]. In Poland, asbestosis as an occupational disease is differentiated with radiographic changes starting from the category of density $1 / 1$ [9].

Periodic chest radiography examinations in former workers of asbestos processing plants (the Amiantus Programme) were performed in 2001-2010. The results have shown that the adoption of international criteria for the density of opacities (from 1/0) would result in the increase in the number of people with diagnosed asbestosis by a total of $13 \%$, depending on the sector, from $8.2 \%$ in those exposed during the production of waterproofing materials, and up to $26 \%$ in those exposed during the production of sealing materials (Table 4). a)

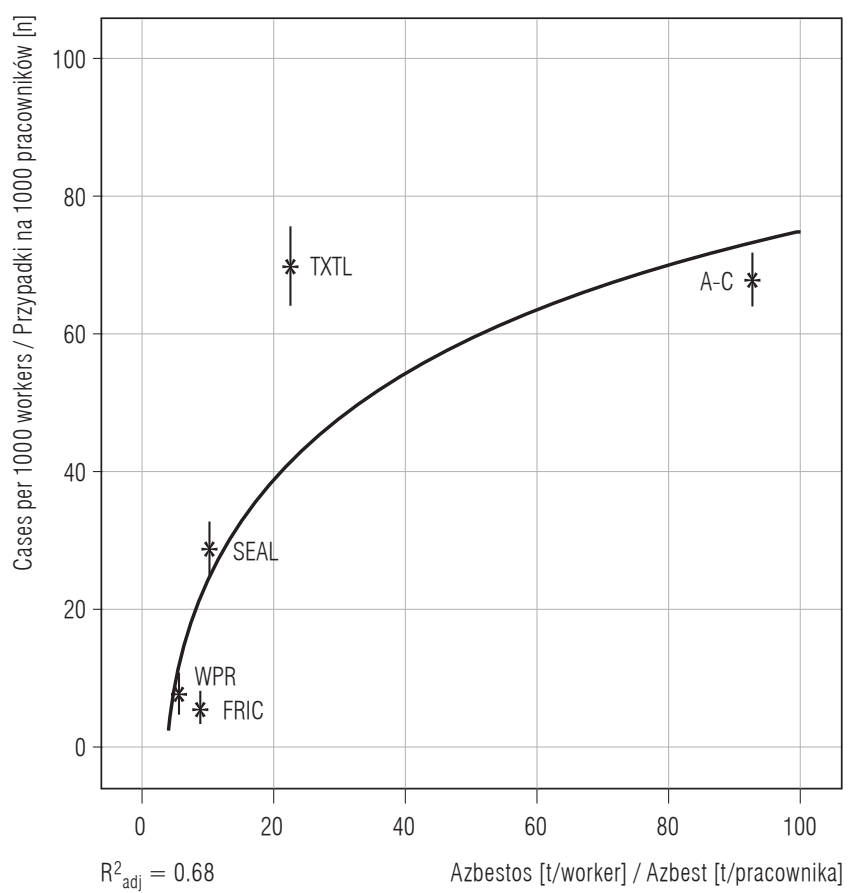

b)

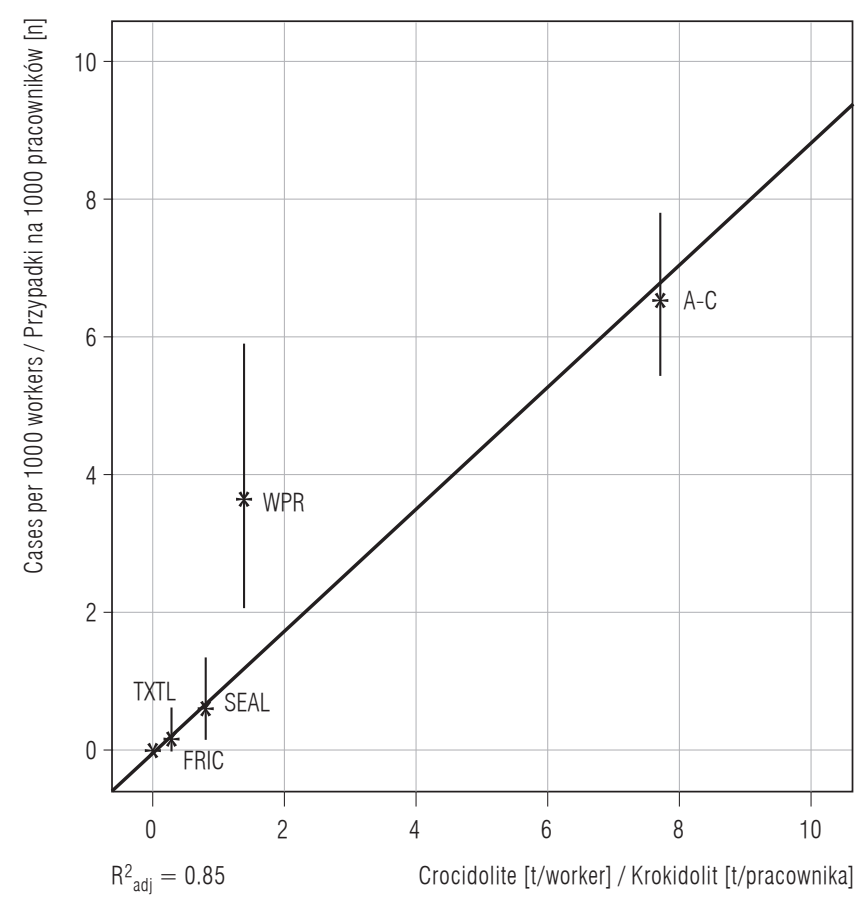

$\mathrm{R}^{2}$ - coefficient of determination / współczynnik determinacji.

A-C - asbestos-cement / azbestocement, TXTL - textile / produkty włókiennicze, SEAL - sealants / produkty uszczelniające, FRIC - frictional / produkty cierne, WPR - waterproofing / produkty hydroizolacyjne. Error bars represent 95\% confidence intervals / odcinki oznaczają 95\% przedziały ufności.

Fig. 1. Asbestosis a) and pleural mesothelioma b) incidence in 5 types of asbestos processing plants according to the total asbestos and crocidolite consumption

Ryc. 1. Zapadalność na a) azbestozę i b) międzybłoniaka w 5 rodzajach zakładów przetwórstwa azbestu w zależności od zużycia azbestu ogółem i krokidolitu 
Table 3. Regression analyses of the incidence of asbestos-related diseases $(\mathrm{y})$ versus the consumption of the total asbestos $\left(\mathrm{x}_{1}\right)$ and crocidolite $\left(\mathrm{x}_{2}\right)$

Tabela 3. Analiza regresji zapadalności na choroby azbestozależne (y) w zależności od zużycia azbestu ogółem $\left(\mathrm{x}_{1}\right)$ i krokidolitu $\left(\mathrm{x}_{2}\right)$

\begin{tabular}{|c|c|c|c|c|c|c|c|}
\hline \multirow{2}{*}{$\begin{array}{l}\text { Asbestos-related diseases } \\
\text { Choroby azbestozależne }\end{array}$} & \multicolumn{7}{|c|}{$\begin{array}{l}\text { Regression parameters per } 1 \text { worker } \\
\text { Parametry regresji na } 1 \text { pracownika }\end{array}$} \\
\hline & $\mathrm{B}_{0}(95 \% \mathrm{CI})$ & SE & $\mathrm{p}$ & $\mathrm{B}_{1}(95 \% \mathrm{CI})$ & SE & $\mathrm{p}$ & $\mathrm{R}^{2}$ \\
\hline \multicolumn{8}{|l|}{ Asbestosis / Azbestoza } \\
\hline asbestos (total) / azbest (ogółem) & $\begin{array}{c}-28.22 \\
(-69.77-3.34)\end{array}$ & 21.20 & 0.275 & $\begin{array}{c}22.37 \\
(8.03-36.70)\end{array}$ & 7.31 & 0.055 & 0.68 \\
\hline crocidolite / krokidolit & $\begin{array}{c}44.55 \\
(19.29-69.81)\end{array}$ & 12.89 & 0.041 & $\begin{array}{c}6.84 \\
(-9.94-23.62)\end{array}$ & 8.56 & 0.483 & 0.00 \\
\hline \multicolumn{8}{|l|}{ Mesothelioma / Międzybłoniak } \\
\hline asbestos (total) / azbest (ogółem) & $\begin{array}{c}0.45 \\
(-1.79-2.69)\end{array}$ & 1.14 & 0.720 & $\begin{array}{c}0.06 \\
(-0.01-0.12)\end{array}$ & 0.03 & 0.175 & 0.35 \\
\hline crocidolite / krokidolit & $\begin{array}{c}0.0 \\
(-0.01-0.01)\end{array}$ & 0.004 & 0.999 & $\begin{array}{c}0.90 \\
(0.54-1.27)\end{array}$ & 0.19 & 0.017 & 0.85 \\
\hline
\end{tabular}

$\mathrm{B}_{0}$ - intercept of regression line / punkt przecięcia linii regresji, CI - confidence interval / przedział ufności, $\mathrm{B}_{1}$ - slope of regression line / współczynnik nachylenia,

$\mathrm{SE}$ - standard error / błąd standardowy, $\mathrm{R}^{2}$ - coefficient of determination / współczynnik determinacji.

Regression equations / Równanie regresji:

- asbestosis / azbestoza: $\mathrm{y}=-28.22+22.37 \ln \mathrm{x}_{1}$, where $\ln$ - logarithm natural / logarytm naturalny.

- mesothelioma / międzybłoniak: $\mathrm{y}=0.9 \mathrm{x}_{2}$.

Table 4. Dissimilarity in diagnosis asbestosis from the density of small irregular s-, t-, u-type opacities in X-ray images according to Polish and international criteria, 2001-2010

Tabela 4. Rozbieżność w rozpoznawaniu azbestozy na podstawie gęstości małych nieregularnych zacienień typu s, t, u w obrazie rtg. według polskich i międzynarodowych kryteriów w latach 2001-2010

\begin{tabular}{|c|c|c|c|}
\hline \multirow[b]{2}{*}{$\begin{array}{l}\text { Type of products } \\
\text { Rodzaj produktów }\end{array}$} & \multirow{2}{*}{$\begin{array}{c}\text { Patients } \\
\text { Pacjenci } \\
\text { [n] }\end{array}$} & \multicolumn{2}{|c|}{$\begin{array}{c}\text { Diagnosing asbestosis } \\
\text { Rozpoznanie azbestozy } \\
{[\%]}\end{array}$} \\
\hline & & $\begin{array}{c}\text { Polish criteria } \\
\text { polskie kryteria } \\
\text { (gęstość / density: } \\
1 / 1-2 / 3 \text { ) }\end{array}$ & $\begin{array}{l}\text { international criteria } \\
\text { międzynarodowe kryteria } \\
\text { (gęstość / density: } \\
1 / 0-2 / 3 \text { ) }\end{array}$ \\
\hline Textile / Włókiennicze & 262 & 31.7 & 45.8 \\
\hline Sealants / Uszczelniające & 277 & 10.1 & 36.1 \\
\hline Frictional / Cierne & 477 & 3.6 & 15.5 \\
\hline Waterproofing / Hydroizolacyjne & 526 & 6.5 & 14.7 \\
\hline
\end{tabular}

\section{Mesothelioma}

Pleural mesothelioma cases were observed only among employees of the plants ever processing crocidolite, even in very small amounts (Table 2). The total number of cases of mesothelioma was 138 , which represents $43.7 \%$ of all of the occupational mesothelioma cases in Poland. Almost $67 \%$ of the cases of mesothelioma among workers involved in asbestos processing occurred in the period 2001-2012, i.e., during the continuation of the Amiantus Programme. The average annual number of mesothelioma cases during that period was almost 4-fold higher than that in the years 1976-2000 (7.7 vs. 1.8).

The Figure 1 shows plots of the pleural mesothelioma incidence rate associated with crocidolite consumption. A positive linear relation between the cro- 
cidolite consumption per capita and the mesothelioma incidence can be clearly seen. The crocidolite consumption per person was a strong predictor of mesothelioma incidence, with an adjusted $\mathrm{R}^{2}=0.85(\mathrm{p}=0.017)$. The slope $\left(B_{1}\right)$ of the regression line suggests that the rise of the crocidolite consumption by 1 tonne resulted in about one case of mesothelioma per 1000 employees. However, no such relationship was found for the total volume of asbestos consumption, with an adjusted $\mathrm{R}^{2}$ value of $0.35(\mathrm{p}=0.175)$ (Table 3$)$.

Regardless of the production type of the plant, a similar number of cases of mesothelioma was associated with $10000 \mathrm{t}$ of the crocidolite processed, with the exception of the very small waterproofing sector. The average number of cases of mesothelioma per 1000 employees was almost 3.2. The highest rates were noted in the workers of the asbestos-cement plants (6.54) and in the workers producing waterproofing materials (3.64) (Table 2).

\section{DISCUSSION}

The ecological relationship between the amounts of historical asbestos consumption and frequency of asbestos-related diseases in the general population is becoming a more and more frequent subject of descriptive analyses. Asbestos consumption per capita in the historical context is a surrogate for the exposure level of a population, which allows to analyse and predict the incidence of pleural mesothelioma in individual countries and in the global scale [10-16].

Poland has no asbestos deposits. The amount of imported asbestos and the annual consumption of about $1.7 \mathrm{~kg}$ per 1 worker (during the period of the highest consumption) ranks Poland at the level of the countries with low consumption of, especially, the crocidolite imported for economic purposes only in small amounts [17]. In the present study, after collecting full data on the amounts of asbestos processed in the asbestos industry plants and on the numbers of occupational disease cases since 1970 up to the present, we have analysed the incidence of asbestosis and pleural mesothelioma as the pathologies most characteristic of asbestos exposure. In the case of asbestos processing exposure to only one type of fibre is extremely rare. Asbestos products were usually made of a mixture of 2 or more types of asbestos fibres, blended in varying proportions depending on the processing method and the required characteristics of the final product. The analysed plants processed practically only 2 types of asbestos - chrysotile and crocidolite.
The highest risk of asbestosis was recorded in the textile sector. A similar level was reported in the production of sealing items (gaskets), predominantly made of asbestos yarn. In comparison with other sectors, the textile asbestos processing sector was characterized by very high concentrations of dust, especially in the preparatory, spinning and weaving departments. This was reflected in significantly higher rates of deaths due to asbestos-related diseases recorded in the historical cohorts of the employees in that sector [18-20]. Noteworthy, as emphasized by several authors [21-24], is the incidence of pleural mesothelioma in the workers of the plants adding crocidolite to their products. Despite the significant risk of asbestosis observed in our analysis, only 2 cases of pleural mesothelioma were registered in the textile sector and both cases dated back to the period, during which crocidolite was used in the production process.

The analysis showed that the greatest risk of pleural mesothelioma was reported among the workers of asbestos-cement plants and in the smallest sector of the asbestos-processing industry i.e., manufacturing waterproofing products which processed about $1 \%$ of the asbestos imported. It should be noted, however, that out of the total $22000 \mathrm{t}$ of asbestos processed in the waterproofing sector, $25 \%$ was crocidolite. Taking into account the fact that in the mid-seventies, many operations were performed manually, the highest concentrations of asbestos dust were recorded in the workstations where cutting bags, feeding material to the machines as well as cutting and polishing the final products were performed. Among the individual sectors of the asbestos-processing industry, the highest concentrations of asbestos fibres were recorded in the production of yarns, fabrics and textile insulation materials.

A very strong association between the consumption of the crocidolite processed and the incidence of pleural mesothelioma, and the lack of such relationship for the total volume of asbestos consumption per capita confirm biological aggressiveness of crocidolite. The number of cases of disease per $10000 t$ of the material processed may be regarded as an indirect indicator of working conditions. The data presented in this analysis shows that the sector of friction materials was rated best in that respect, with about 6 cases of asbestosis per $10000 \mathrm{t}$ of the asbestos processed, which is 6 -fold less than in the textile sector. The indicator of the use of crocidolite and mesothelioma points to poor working conditions prevailing in the waterproofing products sector. An approximately 3 -fold greater (relative to 
asbestos-cement, textile and sealant plants) number of mesothelioma cases resulted from 10000 of crocidolite.

The high number of recorded asbestosis and mesothelioma cases in the period over the years 2001-2012, which was several times higher than that recorded in the previous period, was a result of 2 factors - the long latency period of the diseases and the implementation of the Amiantus Programme which significantly increased their detectability.

The presented study has some limitations, including the use of raw incidence rates due to the lack of data on person-years. The per capita asbestos consumption was calculated for the well-documented aggregated data for a relevant period of the operation of factories. Another limitation of this study is that the incidence of occupational mesothelioma can be underestimated, compared with data from other countries. The major factors accounting for the underrated occupational fraction of mesothelioma are difficulties in diagnosing this rare cancer and low cumulative dose of asbestos dust due to short periods of employment [17]. A high proportion of asbestos workers were employed for a short time.

The previously mentioned limitations should be taken into consideration when interpreting the results, however a major strength of this study is that the analysis was based on the data covering all of the occupational asbestos-related diseases and the complete, reliable data on asbestos consumption in the territory Poland.

\section{CONCLUSIONS}

There were significant differences between the incidence of asbestosis depending on the manufactured products. The highest risk of asbestosis was associated with manufacturing textiles products. The differences concerning the risk result mainly from the historical lack of proper industrial hygiene and procedures that would minimize asbestos exposure, therefore differences in the concentration of asbestos dust in the analysed sectors can be observed.

Cases of pleural mesothelioma were observed only among the employees of plants ever processing crocidolite (employed during the period when crocidolite was processed in those plants). We found a correlation between the incidence of pleural mesothelioma and the volume of the crocidolite processed per capita. The increase of the crocidolite consumption per capita by $1 \mathrm{t}$ resulted in 1 additional case of mesothelioma per 1000 employees. As regards the type of manufactured products, contrary to the case of asbestosis, a similar volume of processed crocidolite resulted in one case of pleural mesothelima (except for the waterproofing sector).

This observation confirms the association between the exposure to crocidolite and the incidence of pleural mesothelioma and points to the absence of such a link for the exposure to chrysotile. The results confirm the still controversial thesis about the lack of sufficient proof of a causal link between exposure to chrysotile only and the incidence of pleural mesothelioma. The hypothesis about the lack of such dependence is very important in the context of environmental exposure to asbestos.

Finally, dissemination of information concerning the use of materials containing asbestos, in particular those containing crocidolite, which are still a source of fiber emissions, is essential from the public-health point of view, and provides recommendations on reducing health risks.

\section{REFERENCES}

1. Marek K. [Asbestos-related carcinogenic risk]. Med Pr. 2002;53(6):447-9. Polish.

2. Albin M, Magnani C, Krstev S, Rapiti E, Shefer I. Asbestos and cancer: An overview of current trends in Europe. Environ Health Perspect. 1999;107 Suppl 2: 289-98, http://dx.doi.org/10.1289/ehp.99107s2289.

3. LaDou J. The asbestos cancer epidemic. Environ Health Perspect. 2004;112:285-90.

4. Szeszenia-Dąbrowska N, Sobala W, Świątkowska B, Stroszejn-Mrowca G, Wilczyńska U. Environmental asbestos pollution - Situation in Poland. Int J Occup Med Environ Health. 2012;25(1):1-11, http://dx.doi. org/10.2478/s13382-012-0003-0.

5. Neumann V, Löseke S, Nowak D, Herth FJ, Tannapfel A. Malignant pleural mesothelioma: Incidence, etiology, diagnosis, treatment, and occupational health. Dtsch Arztebl Int. 2013;110(18):319-26, http://dx.doi.org/10. 3238/arztebl.2013.0319.

6. Stayner L, Welch LS, Lemen R. The worldwide pandemic of asbestos-related diseases. Ann Rev Public Health. 2013;34:205-16, http://dx.doi.org/10.1146/annurev-publhealth-031811-124704.

7. $\mathrm{R}$ Development Core Team. A language and environment for statistical computing. Vienna: R Foundation for Statistical Computing; 2013.

8. International Labour Office. Guidelines for the use of ILO International Classification of Radiographs of Dust Diseases. Geneva: ILO; 1980. 
9. Marek K. [Occupational diseases]. Warszawa: Wydawnictwo Lekarskie PZWL; 2001. Polish.

10. Szeszenia-Dąbrowska N, Szubert Z. [Programme of prophylactic medical examinations of former asbestos workers - Amiantus]. Med Pr. 2002;53(6):451-6. Polish.

11. Tossavainen A. Global use of asbestos and the incidence of mesothelioma. Int J Occup Environ Health. 2004;10(1): 22-5, http://dx.doi.org/10.1179/oeh.2004.10.1.22.

12. Marinaccio A, Montanaro F, Mastrantonio M, Uccelli R, Altavista P, Nesti M, et al. Predictions of mortality from pleural mesothelioma in Italy: A model based on asbestos consumption figures supports results from age-period-cohort models. Int J Cancer. 2005;115(1): 142-7, http://dx.doi.org/10.1002/ijc.20820.

13. Lin RT, Takahashi K, Karjalainen A, Hoshuyama T, Wilson D, Kameda T, et al. Ecological association between asbestos-related diseases and historical asbestos consumption: An international analysis. Lancet. 2007;369(9564):844-9, http://dx.doi.org/10.1016/S01406736(07)60412-7.

14. Nishikawa K, Takahashi K, Karjalainen A, Wen CP, Furuya S, Hoshuyama T, et al. Recent mortality from pleural mesothelioma, historical patterns of asbestos use, and adoption of bans: A global assessment. Environ Health Perspect. 2008;116(12):1675-80, http://dx.doi. org/10.1289/ehp.11272.

15. Dos Santos Antao VC, Pinheiro GA, Wassell JT. Asbestosis mortality in the USA: Facts and predictions. Occup Environ Med. 2009;66(5):335-8, http://dx.doi. org/10.1136/oem.2008.039172.

16. Le GV, Takahashi K, Park EK, Delgermaa V, Oak C, Qureshi AM, et al. Asbestos use and asbestos-related diseases in Asia: Past, present and future. Respiro- logy. 2011;16(5):767-75, http://dx.doi.org/10.1111/j.14401843.2011.01975.x.

17. Szeszenia-Dąbrowska N, Świątkowska B, Szubert Z, Wilczyńska U. Asbestos in Poland: Occupational health problems. Int J Occup Med Environ Health. 2011;24(2): 142-52, http://dx.doi.org/10.2478/s13382-011-0020-4.

18. Pira E, Pelucchi C, Buffoni L, Palmas A, Turbiglio M, Negri E, et al. Cancer mortality in a cohort of asbestos textile workers. Br J Cancer. 2005;92(3):580-6, http:// dx.doi.org/10.1038/sj.bjc.6602240.

19. Hein MJ, Stayner LT, Lehman E, Dement JM. Followup study of chrysotile textile workers: Cohort mortality and exposure-response. Occup Environ Med. 2007;64(9): 616-25, http://dx.doi.org/10.1136/oem.2006.031005.

20. Wang XR, Yu ITS, Qiu H, Wang MZ, Lan YJ, Tse LY, et al. Cancer mortality among Chinese chrysotile asbestos textile workers. Lung Cancer. 2012;75(2):151-5, http://dx.doi.org/10.1016/j.lungcan.2011.06.013.

21. Newhouse ML. A study of the mortality of workers in an asbestos factory. Br J Ind Med. 1969;26(4):294-301.

22. Dement JM, Harris Jr RL, Symons MJ, Shy C. Estimates of dose - Response for respiratory cancer among chrysotile asbestos textile workers. Ann Occup Hyg. 1982;26(8): 869-87, http://dx.doi.org/10.1093/annhyg/26.8.869.

23. McDonald AD, Fry JS, Woolley AJ, McDonald JC. Dust exposure and mortality in an American factory using chrysotile, amosite and crocidolite in mainly textile manufacture. Br J Ind Med. 1983;40(4):368-74.

24. Szeszenia-Dąbrowska N, Wilczyńska U, Szymczak W. A mortality study among male workers occupationally expose to asbestos dust in Poland. Pol J Occup Med. 1988;1(1):77-87.

This work is available in Open Access model and licensed under a Creative Commons Attribution-NonCommercial 3.0 Poland License / Ten utwór jest dostępny w modelu open access na licencji Creative Commons Uznanie autorstwa - Użycie niekomercyjne 3.0 Polska - http://creativecommons.org/licenses/ by-nc/3.0/pl. 